\title{
記号の世界に和ける抽象情報と具体情報
}

川野洋

\section{Abstract Information and Concrete Information in the World of Signs}

\section{Hiroshi Kawano}

In the world of signs surrounding us, there are two sorts of information which look contradictory with one another, (1) abstract information as "negentropy" being the measure of order by Wiener's formulation, and (2) concrete information as "entropy" being the measure of disorder by Shannon's formulation. The former, possessed by the logical composition of virtual message, informs about another one and the later, generated in the actual performance of this composition by coded signals, informs about oneself. But properly the sign can inform oneself as well as another one, and the composition and performance are two necessary stages of communication. Accordingly these two informations can be coexistent with one another in the world of signs, sounding under a sonorous counterpoint.

\section{はじめに一一記号の世界と情報}

われわれはつねにある特定の世界のなかにいる。それは雑然とした「もの」の センス・データとして与えられるにすぎないような，とらえよらのない多様で変 幻つねないものではない。われわれの世界は一定の性格をもって構造づけられて いる。われわれは自分たちをとりまく，そして自分たちが問題にしょうとしてい るこの世界を，一定のシンボル・レパートワールとそれらが世界へと組み立てら れるコンポジションによって定義することができる。すなわちシンボル・レパー 
トワールが $\mathrm{n}$ 種類 $\left(\mathrm{x}_{1}, \mathrm{x}_{2}, \cdots, \mathrm{x}_{n}\right)$ ，そのコンポジションを $\mathrm{F}$ とする世界 $\mathrm{W}$ はつぎ のように定式化される。

$$
\mathrm{W}=\mathrm{F}\left(\mathrm{x}_{1}, \mathrm{x}_{2}, \cdots, \mathrm{x}_{n}\right)
$$

そしてわれわれが何かを語り，何かを考光る場合，その世界は主題によってい くつかの有限個の語彙をもち, それらを命題システムへと構成する文法ないし変 形規則をもつし，またわれわれが芸術（たとえば音楽）の世界をとりあげる場 合，われわれはそこに芸術の世界を作りあげている楽音レパートワールと対位法 や和声のコンポジションをみいだす。このような世界をわれわれは記号の世界と いってよかろう。記号の世界は, シンボル・レパートワールといら物的要素によ って担われるが, その本質は物的要素の論理的構成であって, けっして単なる 「もの」の集塊ではない。記号の世界はシンボル・レパートワールの構文論的そ して意味論的論理構造であるコンポジションによって規定されるという意味で， その本性はヴァーチュアルなあり方をもつ。この記号のヴァーチュアルな何か を, われわれは記号のなかにみいだして，何か新しいものにふれたと感じる。記 号のこのヴァーチュアルルな何かを「情報」とよぶことにする。そうすると，わ れわれの世界は「もの」にみたされているのではなく, 情報にみたされているの だといってよいであろう。

$$
\text { エントロピーとしての情報 }
$$

われわれの世界は情報の発生源をなしている。この情報発生源としての世界を 構成するシンボル・レパートワールを $\mathrm{x}_{1}, \mathrm{x}_{2}, \cdots, \mathrm{x}_{n}$ とし，これらのレパートワー ルが記号世界をなすメッセージとなって出現する確率を $\mathrm{p}_{1}, \mathrm{p}_{2}, \cdots, \mathrm{p}_{n}$ とすると， 記号メッセージの発生源であるこの情報源はつぎのような確率マトリックス $\mathrm{F} て ゙$ 表現される。

$$
\mathrm{F}=\left(\begin{array}{lllll}
\mathrm{x}_{1} & \mathrm{x}_{2} & \mathrm{x}_{3} & \cdots & \mathrm{x}_{n} \\
\mathrm{p}_{1} & \mathrm{p}_{2} & \mathrm{p}_{3} & \cdots & \mathrm{p}_{n}
\end{array}\right)
$$

このような情報源から，そのシンボル・レパートワールを選択的に組み合わせ たいろいろなメッセージが発生するのであるが, このメッセージの情報はどのよ 
らな性質をもつであろうか。シャノンはここでメッセージ1レパードワールあた りの平均情報量を，この情報源のエントロピーHでおきかえる。エントロピーと は情報源の確率的不確定状態の尺度で，そこからどのようなメッセージが発生す るのか予測できない分からなさの量を示するのである。レパートワールの出現す る確率が平均した一様分布をとっている場合, どのレパートワールの出現も和な じ確からしさをもつから，どのレパートワールが出現するかといら分からなさは 最大になり，反対にレパートワールの出現確率分布がするどい凹円をもった非平 均的なものになれば，どのレパートワールが出現しやすいかという予測がしやす くなって，まえの場合に比べて情報源のエントロピーは低下する。そしてこのエ ントロピーの量はつぎのように定式化され，この量Hが，とりもなおさず，その 情報源が発するメッセージ 1 レパートワールの情報量といらことになる。

$$
\mathrm{H}=-\sum^{\mathrm{n}} \mathrm{pi} \log \mathrm{pi}
$$

しかし，情報源からの実際のメッセージは，各レパートワールがそれぞれ独立 に選択されてあらわれることはなく、いわゆるマルコフ・チェインをなしている。 ゆ光に先行レパートワールの何であるかによって後続レパートワールの出現源率 は束縛され，1 たた 0 の方にズレさせられる。つまり実際のメッセージは， それを構成するレパートワールの間につよい多連結合関係があって, この多連レ パートワール間での出現遷移確率は, 独立したレパートワールの出現確率より も，その分布が非平均化されていることが知られている。したがって実際のメッ セージの情報量 $\mathrm{H}^{\prime}$ は, さきのバラバラな独立のレパートワールが出現すると仮定 した場合の情報量 $\mathrm{H}$ よりも減少することになる。この相対情報減少度を圥長度 $\mathrm{R}$ とすれば，このメッセージはつぎのような圥長度をもつ。

$$
\mathrm{R}=1-\mathrm{H}^{\prime} / \mathrm{H}
$$

この圥長度は,メッセージに和ける出現レパートワールの多連結合の強さを示 すものであるから，圥長度の大きいメッセージほど，レパートワール間の親密さ がつよいといらことになり，したがってメッセージのあらわれ方も予測しやすく なる。こうしてて長度はメッセージのなかにあらわれる, シンボル・レパートワ 
ールのコンポジションの秩序の量であるといらことができるであろら。

以上の点から，われわれはつぎのようにいらことができる。圥長度が小さくし たがってコンポジションに秩序の少ないほど，そのメッセージの実際の情報量は 高くなると。つまり出現シンボル・レパートワールに不確定性がつよく, その出 現の予測ができない無秩序なメッセージほど，その情報は高くなるといえるので ある。そしてわれわれは，このような高情報メッセージが (1) 構成要素であるシ ンボル・レパートワールの種類が多く，（2）その確率分布が凹凸の少ない，一様 に平均化されているものであることを指摘することができると思う。こうして innovationとオリジナリティに富んだランダムな記号ほど高い情報を示すことに なる。たとえば，芸術に特いてこれをみれば，このような情報特性は古典主義芸 術に対する現代芸術のなかにみいだされるであろら。古典主義芸術は形態が明膫 で対象的意味をもち，たとえば人物の顔だと，どこにどのような形の目がきて， それに対し鼻や口はどのような位置にどのように描かれるというはっきりしたコ ンポジションの支配をうけている。したがって描かれるその人物の顔はを党もっ て予想される構造をもち，その絵は大きい圥長度をもつ。そしてわれわれはこの ような絵を平凡で陳腐だといら。これに対し現代芸術の作品はこのような対象的 意味や形態を, 印象派の点描のような多くの種類のミクロなターシでうちくだ きまたシュールやダダのコラージュにみるような，思いがけないモチーフを思 いがけない組み合わせで配置するといった，確率分布の平均化したランダムなコ ンポジションをみせている。この種の現代芸術の innovation は, 伝統芸術の古 典主義的 convention で陳腐化した芸術の情報貧困に, 新しい生気あるオリジナ リティをとりもどさせようとする一種のショック療法の効果をるつものと考觉る ことができるであろう。

ネゲントロピーとしての情報

シャノンが情報を無秩序の尺度であるエントロピーとしてとらえたのに対し て, ウィーナーの「情報」の解釈は対照的である。

ここにたとえば明日の天気についての中央気象台の予報があるとする。この天 
気予報のメッセージがつぎのような 2 種類のものである場合,

(1) 明日はハレ

（2）明日はハレまたはクモリ，ときどきアメ

われわれは（1）の方が予報としての情報が高いと感じ，（2）の方はそのような 情報はあまりないと感じる。それはなぜかとい光ば，「明日はハレ」の方はメッセ 一ジに暧昧さがなく，何をいっているのかがはっきりしているのに比べて，「明 日はハレまたはクモリ，ときどきアメ」の方は，易者が手相をみて「あなたは慎 重であるが半面また大胆」といら場合のように，いっていることが多義的で，結 局何もいってないのとそら大差はないことになるからである。前のメッセージは 明日の天気について明膫に何かを告げてくれるが，後のメッセージはウヤムヤで 何も告げてくれないようである。このことは（2）のメッセージが「明日は宁う」 といらアメともハレともつかないいい方をする場合も拉なじで，やはり「明日は 宁レ」では何のことか分からない。つまり天気予報としての情報はとのような場 合，低いといわねばならない。

以上のように考光ると，この天気についての予報メッセージの情報の量は，そ の表現しいおうとするところが一義的明瞭性をとなえているかどうかによってき まるといえる。ウィーナーは「ェントロピーが無秩序の尺度であるように，記号 によって与兄られる情報は秩序の尺度である」という。つまりウィーナ一的にい えば,メッセージが一義的に解釈できるよらな明瞭な秩序だった構造をもつ場 合，それは高い情報を示し，逆にどらでもいいような多義的構造をもつ場合，低 い情報しか示しえないといらことになる。こうしてシャノンの情報ニエントロピ 一説に対し, ウィーナーは情報＝ネゲントロピー説をたてる。ここでは情報はエ ントロピーの減少量に和きかえられる。「明日は八レ」といら予報によって，明 日の天気の不確定性（エントロピー）は，この予報に暧味さ（不確定性）がない 限り，解消するであろう。しかし「明日はハレまたはクモリ，ときどきアメ」と いら予報はそれ自身に不確定性がつよく，それによって明日の天気のエントロピ 一はそら減少するわけではない。このようにメッセージが，その告げようとする 出来事のエントロピーを減少させることが多ければ多いほど，そのメッセージの 
ネゲントロピーとしての情報は高くなり，逆にェントロピーの減少量の少ないメ ッセージは低い情報しか示しえないといえる。これを芸術に例をとってみれば, たとえばデフォルメされたり，タッチのあらあらしい色面を自由に並べた抽象画 は，無秩序なコンポジションを示し，何をあらわそうとしているのか分からない といら意味で情報が低い。それに対して逆に古典主義の作品は，対象的に線や形 体や色がディテールまで明瞭に仕上げられ，それが何をあらわとらとしているか が細かく分かるといら意味で高い情報をもつといえるであろう。

ここでわれわれは情報の二義性につきあたることになる。一方にシャノンのい ら無秩序の尺度としてェントロピーではかられる情報があり, 他方でウィーナー のいら秩序の尺度としてネゲントロピーではかられる情報がある。前者ではメッ セージが午長でなく, innovationとオリジナリティの豊かさを示し，無秩序でラ ンダムであることがその情報特性となり，後者では細部にいたるまで一義的に明 確にされた秩序ある構造をもつことがメッセージの情報特性となる。この無秩序 としての情報と秩序としての情報のパラドックスはいかに処理されたらよいであ ろらか。

抽象情報と具体情報

ここでわれわれは記号の情報についてもっと敩密な規定を与えようと思う。わ れわれは記号のメッセージの情報というあのを考兄てきたが，このメッセージの 情報は何㐫関する情報なのであるか。この点を考慮にいれると, われわれは情報 を「何の何に関する」情報としてとらえる必要があろう。こうしてわれわれは情 報 Iをbの $\mathrm{a}$ に関する情報としてつぎのように定式化する。

$$
\mathrm{I}(\mathrm{b}, \mathrm{a})
$$

ではウィーナー的情報は何の何に関する情報であるか。それは「明日は……」 の明日の天気に関する情報であるといえる。ところでこのメッセージと明日の天 気の関係をみるに, このメッセージは中央気象台が情報源となってそこから発生 するメッセージであるが，その情報源とは別個の明日の天気という出来事につい て告げていて, したがって, メッセージは自己の外にある別個の出来事に関係し 
ている。この種の情報は，たと党ば「話」などでもみられ，話は文字になったり 声になって存在するが，それはそのような話文字や話声とは別個の「天下国家」 であったり，「他人のゴシップ」であったりする。これに対してシャノン的情報を みれば，これはメッセージの，そのメッセージを発生する情報源関する情報で ある。メッセージはその発生情報源をもっていて，それについて何かを告げるわ けである。これはメッセージが結局自分自身について告げることである。たと兄 ば太陽が輻射するさまざまな電磁波は，その発生源である太陽自身について語る ものである。その場合, 電磁波 (メッセージ) の異常は正常よりも, 不規則は規 則よりも高い情報を示す。「明日は……」も, 明日の天気ではなく, 言語発生源に ついての情報といら観点からみれば，「明日はハレ」よりも「明日はハレまたはク

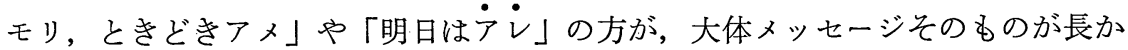
ったり，「ハレ」よりも「アレ」の方が出現確率が小さかったりして, 高い情報を もつはずである。

芸術に例をとり，たとえば音楽をみてみると興味ある情報のこのような二義性 が浮き彫りにされる。音楽とはすず何よりも作曲された作品である。このような 作品は楽譜として存在する。この楽譜としての作品はシンボル・レパートワール として有限個（1オクターヴ 7 音ないし12音）の音符（さらに細分すれば全音符， 2 分音符……がある) をるち，そのコンポジションによって旋律やリズムを構成 していて，りっぱな記号メッセージとしての性質をそなえている。この作品は音 符レパートワールの一定のコンポジションによって, 自然や人生の感情的イメー ジを表現する。それはいらなれば 5 線のうえの「オタマジャクシ」のダンスであ るが，この「オタマジャクシ」は自分の外にある自分とは異質な感情世界につい ての情報を示するのである。この楽譜の情報は演奏家によってらけいれられるも のであって，われわれが享受するものとは拉よそ異なるものである。それでもこ の楽譜の感情世界に関する情報は，その作品のきわめて重要な部分をなして和 り，われわれが「ベートーヴェンは偉大だ」というとき，このような楽譜の情報 についていっているのである。では，われわれは演奏家がするようにその楽譜を 全部暗記してしまったらどうなるであろらか。つまりそこでは楽譜メッセージは 
完全に冗長になって，るはや何ら感情世界についての情報をそれはわれわれに与

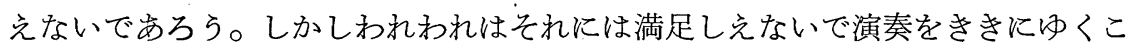
とであろう。われわれはそこでまだ何を求めているのであろらか。演奏は楽譜以 上に何かプラス $\alpha$ 情報をもつのであららか。もしそらだとすれば，この演奏に よるプラス $\alpha$ の情報とはどのよらな情報であろらか。

それは音そのものの情報である。演奏される音は演奏家——楽器といら発音情 報源についての音のあらわれの情報を示している。どの上らな音が出現するかと いら情報を演奏は示す。そしてわれわれは音符のあらわれでなく，その音符が音 としてどんなに鳴りひびくかを知ららと演奏をきにゆくとい光る。ここで楽譜 の情報はウィーナー的な情報で, 楽譜は自分の外飞ある世界について告げるのに 対して, 演奏の情報はシャ, ン的な情報で, 鳴りひびく音の流れは, 自分自身で ある音のあらわれそのるのについて告げているといえる。しかる楽譜情報は少数 の音符と規則的なコンポジションによって規定されるのに比べ, 演奏情報は音色 やダイナミックスなどのレパートワールがー段と多く, その確率的コンポジショ ンも即興と自由な遊戲を加光て変化にとむことを考兄ると, 楽譜情報は秩序を, 演奏情報は逆に無秩序を原則としていることが理解できる。このような情報の二 義性は言語においてるいちじるしく，言語は表現内容としてウィーナ一的情報を もつとともに，話し声のひびき，抑揚，ダイナミックスなどによるプラス $\alpha$ のシ ヤノン的情報をもつことが执なじように理解でさるであらう。

われわれはこの 2 種類の情報をつぎのように定式化してみたい。bの $\mathrm{a}$ 亿関す る情報は, bメッセージによって $\mathrm{a}$ という情報源のエントロピーH（a ）が減少し た量（ネゲントロピー）を示すとすれば，このウィーナー的情報はつぎのように なる。

$$
\mathrm{I}(\mathrm{b}, \mathrm{a})=\mathrm{H}(\mathrm{a})-\mathrm{Hb}(\mathrm{a})
$$

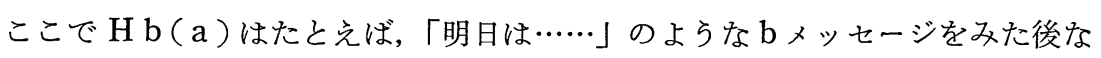
特残る明日の天気 $\mathrm{a}$ のエントロピー（分からなさ）である。しかしここでbメッ セージが a とは独立のものでなく、 a 情報源とのものについてのメッセージでめ るとすれば， bは $\mathrm{a}$ 自身のあらわれとなり，したがって $\mathrm{a} か ゙$ 自分自身を示す情報 
はつぎのようになって，aのエントロピーに特きかわるのである。

$$
\mathrm{I}(\mathrm{a}, \mathrm{a})=\mathrm{H}(\mathrm{a})-\mathrm{Ha}(\mathrm{a})=\mathrm{H}(\mathrm{a})
$$

ただし、は自分自身をあらわにすることによって，すっかり暴露されて不確定性 は 0 になるから, $\mathrm{Ha}$ a (a)=0である。

このようにして自分自身を告げるメッセージの情報は無秩序なエントロピー特 性をもち，他のものについて告げるメッセージの情報は秩序あるネゲントロピー 特性を示すとい壳る。

ウィーナー的情報は記号の内容をさすものであり，シャノン的情報は記号の符 号化された具体的あらわれ方をさするのとい方るが，A. Moles は前者を「意味 情報」(information sémantique) といい，後者を「美的情報」(information esthétique) と名づけている (cf. Abraham Moles: Théorie de l'Information et Percéption Esthétique, 1958)。わたしはこの 2 種類の情報に「抽象情報」と「具体 情報」といら名前をつけることにする。記号は自分以外の何かについて represent するとともに，そのrepresentation を通じて自分自身をむ presentするというこ とができよう。 represent するものは現存しないヴァーチュアルな世界について の情報であり， present するものは現存するアクチュアルな記号自身についての 情報である。そして記号が対象とともに記号自身について何かをあらわす(representation と presentation) ところに，情報の一見パラドックスらしくみえる二 義性が生じるといえる。

$$
\text { メッセージとシグナル }
$$

われわれはコミュニケーションによって情報を変換し伝達する。この過程をシ ヤノンは (情報源 $) \rightarrow($ 送信器 $) \rightarrow($ チャンネル $) \rightarrow($ 受信器 $) \rightarrow($ 目標 $)$ というシェー マで示したが，いまこのシェーマを送信の側からだけみるとつぎのようになる。

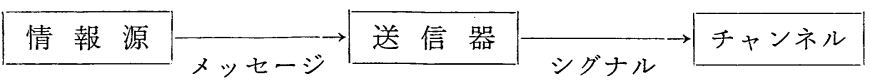

ここで分かるように，コミュニケーションには情報処理の 2 段階がある。一つ の段階では情報源からメッセージが発生し，それはいま一つの段階で符号化され 
てシグナルに変換される。そしてこのシグナルがはじめて一定のチャンネルによ って受信の側へと運ばれる。

メッセージは一定のシンボル・レパートワールを一定の規則によって構成した もので, コンポジションをもつ。しかしこのコンポジションは作曲された楽譜の ようなもので, 構文論的そして意味論的規則を満足させることによって, ある解 釈可能な意味内容をあらわすが，それはまだヴァーチュアルな存在で，物的に具 体化されているのではない。つまりメッセージは純粋にその論理構造をむきだし にしている context-free な記号であるといえる。このメッセージの表現する意 味内容が受信の側へ伝達されるには，チャンネルにのせられねばならず，そのた め物的符号によって具体化されねばならない。このメッセージの具体化をパフォ ーマンスという。パフォームされたシグナルはメッセージの抽象的意味内容に伝 達者の生きたニュアンスを加えて，メッセージを actualize する。このことは楽 譜メッセージが演奏によって actualize されることによって聴き手に伝達される 過程を考兇ればはっきりするであろら。この演奏された音は，もはや楽譜の抽象 的意味内容を表現するのではなく, 演奏者が自由に加えた豊かなニュアンスをも って生きた意味を伝達する。このシグナルの生きた意味は演奏者の心理的，身体 的, 社会的条件に束縛されてメッセージが潤色されたもので, その意味でシグナ ルは context-bound な記号であるとい方る。context-free な記号 (メッセージ) はウィーナー的抽象情報をもつが，それがそのまま伝達されるのではない。それ が伝達されるにはこの抽象情報に, context-bound なシャノン的具体情報がプラ ス $\alpha$ とて付加されねばならない。メッセージのコンポジションは秩序ある一義 的規定性をもつとはいうものの，それはパフォーマンスに拉ける自由の余地をか なり残した枠組の必然性であって，そのなかでシグナル・パフォーマンスの自由 はかなりあり, この自由を消費することによって, 生さた具体情報の伝達が達成 される。ただしパフォーマンスは抽象情報を換えるものではない。パフォーマン スに颃いても記号の意味内容にはなんらの変更もない。パフォーマンスにおいて は，ただ抽象的意味内容にニュアンスが加わるだけである。これは，「ハイ」とい う言葉にも「ハーイ」から「ハイッ」までいろいろのいい方のニュアンスがある 
が，「ハイ」の抽象的意味内容にはなんら変更がないのとおなじである。そしてわ れわれはここに記号の具体情報を規定する実用論的機能に気づくようになる。記 号はメッセージ段階では, 構文論的, 意味論的構造を有していて, それ自体まだ 抽象的であるが，シグナルの段階で実用論的機能を発揮して，生きた具体的はた らきをもつようになり，情報伝達の役割をはたすにいたる。

ただここで注意しておきたいのは, メッセージとシグナル, 抽象情報と具体情 報の全体的関係である。シグナルはメッセージを具体化したものであるから，シ グナルはかならずュンポジションをimplicitにそな光ている。しかしメッセージ はまだかならずしも全部シグナルに変換されているわけではない。そのうちパフ オーマンスに和かれたメッセージだけがシグナルとよばれる。つをりシグナルで ないメッセージは脳のなかにヴァーチュアルに存在する。そして抽象情報とはシ グナルに implicit に内在する部分をふくみ, 全体としてメッセージの所有する情 報であり, 具体情報とは, 具体化されたメッセージであるシグナルによってはじ めて新しく所有される情報である。ゆえにシグナルはメッセージを含意するが， 具体情報と抽象情報は排反的関係にたつ点が注意されねばならない。この全体の 関係はつぎのように図示される。

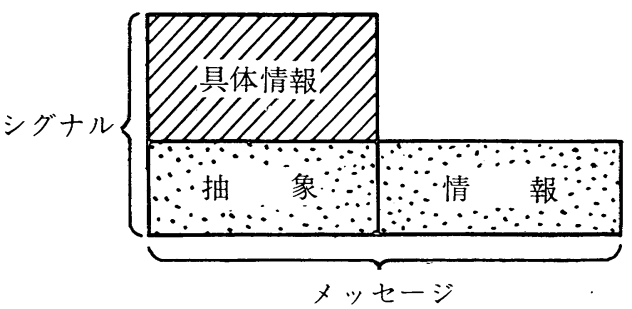

さきにシャノン的具体情報についてのべる際, 自分自身を情報源とするメ் ーシシの情報といらことをいったが，メッセージのうちシグナル化した部分につい て, 自分自身についての情報（具体情報）があてはまり，メッセージのらち非シ グナルの純粋な部分は，自分以外の世界についての情報（抽象情報）が妥当する と考えることができる。

はじあにわれわれをとりまく世界は記号の世界であるといったが，以上の考察 
から，われわれをとりまく世界はシグナルでできていること，そしてこのような シグナルの世界は抽象情報と具体情報, したがって秩序と無秩序の織りなす彩模 様をなすことを知ることがでさる。そしてこのシグナルの世界での抽象情報と具 体情報は，一方は秩序をかなで，他方は無秩序をかなでる多声的対位法をなして いるといえよう。そしてコミュニケーションを司どる役者である記号が，「もの」 をまとった気紛れなシグナルであることも興味ある話である。そしてまたこのシ グナルの世界では，抽象情報と具体情報が，その相反する性格にもかかわらず， 否，相反する性格のゆえに，かえってたがいにひきたてあって共存している姿も 面白い図であるといえよう。

\section{筆者紹介：}

1925年生まれ。1951年, 東大文学部哲学科卒業。現在, 東京都立航空工業短期大 学助教授。

主要著訳書 :

オルドリッチ『芸術の哲学』（共訳, 培風館, 1968), 『コミュニケーションと芸 術』(塙書房, 1968) 